\title{
Prediction of the reactivity of oleum sulfonating agents upon carbamide sulfonation
}

\author{
(C) Andrey A. Degtyarev, ${ }^{*+}$ Alexander Y. Osetrov, and Daria P. Rostova \\ Department of Chemistry and Chemical Technologies. Tambov State Technical University. \\ Soviet St., 106. Tambov, 392000. Russia. Phone: +7 (4752) 63-44-44. \\ E-mail:ad.dycost@gmail.com, ksanset@list.ru,rostova.dariya@yandex.ru
}

*Supervising author, ${ }^{+}$Corresponding author

Keywords: molecular modeling, $\mathrm{SO}_{3}, \mathrm{HSO}_{3}{ }^{+}$, COSMO, oleum, reactivity descriptors.

\begin{abstract}
In this work, a research of the reactivity of sulfonating agents of oleum during sulfonation of carbamide was carried out. Cation $\mathrm{HSO}_{3}{ }^{+}$and sulfur trioxide in monomeric, dimeric, and trimeric forms were chosen as sulfonating agents. The modeling was carried out by the density functional theory (B3LYP5/aug-cc-pVDZ) and the second-order Möller-Plesset perturbation theory (MP2/aug-cc-pVDZ). Simulation was carried out in a vacuum and a polar solvent, which was taken as $100 \%$ sulfuric acid. The solvent was taken into account using the COSMO
\end{abstract} model.

The evaluation of the reactivity of sulfonating agents was carried out on the basis of molecular modeling of sulfonating agents and carbamide. The reactivity descriptors were chosen as the reactivity criteria, such as: energies and the location of the highest occupied molecular orbital and lowest unoccupied molecular orbital, charges on atoms, molecular electrostatic potential, absolute hardness and electrophilicity index.

It was determined that carbamide is a fairly hard Lewis base, the absolute hardness in vacuum is 6.072 , and in a solvent it is 6.635 , so charge control is preferable for its sulfonation reaction.

Based on this, the greatest preference in the analysis of reactivity indices was given to atomic charges and molecular electrostatic potential.

According to the results of the analysis, it was revealed that the highest activity of the studied sulfonating agents is possessed by cation $\mathrm{HSO}_{3}{ }^{+}$, as it has the highest partial charges on atoms $(+3.29$ in vacuum, +3.38 in a solvent), has the highest electrophilicity (13.45 in a vacuum, 5.35 in a solvent) and does not have steric hindrance factor in contact with the carbamide molecule. Among the forms of sulfur trioxide, preference can be given to both

monomeric (highest activity, but there are steric hindrance factor) and trimeric (least steric hindrance factor).

\section{References}

[1] N.V. Orlova, A.G. Yashchenko, A.Yu. Orlov, A.N. Koliukh, D.Yu. Pshichkina. Improvement of crystallisation stage in production of sulfamic acid. Transactions of the Tambov State Technical University. 2014. Vol.20. No.4. P.780-786.

[2] W.H. Brown, T. Poon. Introduction to Organic Chemistry. Wiley. 2017. 696p.

[3] H. Cerfontain. Sulfur trioxide sulfonation of aromatic hydrocarbons. Recueil Des Travaux Chimiques Des Pays-Bas. 1985. Vol.104. No.6. P.153-165. https://doi.org/10.1002/recl.19851040602

[4] G. Dado, E.A. Knaggs, M.J. Nepras. Sulfonation and Sulfation. In: Kirk-Othmer Encyclopedia of Chemical Technology. New York: Wiley. 2006. https://doi.org/10.1002/0471238961.1921120611140107.a01.pub2

[5] S. Moors, X. Deraet, G. Van Assche, P. Geerlings, F. De Proft. Aromatic sulfonation with sulfur trioxide: mechanism and kinetic model. Chemical science. 2016. Vol.8. No.1. P.680-688. https://doi.org/ 10.1039/C6SC03500K

[6] G. Koleva, B. Galabov, J. Kong, H.F. Schaefer and P.V.R. Schleyer. Electrophilic Aromatic Sulfonation with SO3: Concerted or Classic SEAr Mechanism? J. Am. Chem. Soc. 2011. Vol.133. No.47. P.1909419101. https://doi.org/10.1021/ja201866h

[7] Дегтярев А.А. и Тришина А.В. Исследование механизма сульфирования карбамида олеумом методом теории функционала плотности. Бутлеровские сообщения. 2019. T.59. №8. C.32-39. DOI: 10.37952/ROI-jbc-01/19-59-8-32; [A.A. Degtyarev, and A.V. Trishina. Research the sulfonation mechanism of urea in oleum by density functional theory calculation. Butlerov Communications. 2019. Vol.59. No.8. P.32-39. DOI: 10.37952/ROI-jbc-01/19-59-8-32] 
PREDICTION OF THE REACTIVITY OF OLEUM SULFONATING AGENTS UPON CARBAMIDE SULFONATION 64-72

[8] R.J. Gillespie and E. Robinson. The raman spectra of liquid sulphur trioxide and solutions of sulphur trioxide in inert solvents. Canadian Journal of Chemistry. 2011. Vol.39. P.2189-2200. https://doi.org/10.1139/v61-291

[9] R. Cammi, and J. Tomasi. Remarks on the use of the apparent surface charges (ASC) methods in solvation problems: Iterative versus matrix inversion procedures and the renormalization of the apparent charges. J. Comput. Chem. 1995. Vol.16. No.12. P.1449-1458. https://doi.org/10.1002/jcc.540161202

[10] A. Klamt, G. Schüürmann. COSMO: A New Approach to Dielectric Screening in Solvents with Explicit Expressions for the Screening Energy and its Gradient. J. Chem. Soc. Perkin Trans. 1993. Vol.2. P.799-805. https://doi.org/10.1039/P29930000799

[11] C. Amovilli, B. Mennucci. Self-consistent-field calculation of Pauli repulsion and dispersion contributions to the solvation free energy in the polarizable continuum model. Journal of Physical Chemistry B. 1997. Vol.101. No.6. P.1051-1057. https://doi.org/10.1021/jp9621991

[12] M. Liller. Reaction Mechanisms in Sulphuric Acid and other Strong Acid Solutions. San Diego: Academic Press inc. 1971.

[13] A. Klamt, F. Eckert, W. Arlt. COSMO-RS: An Alternative to Simulation for Calculating Thermodynamic Properties of Liquid Mixtures. Annual review of chemical and biomolecular engineering. 2010. Vol.1. No.1. P.101-122. https://doi.org/10.1146/annurev-chembioeng-073009100903

[14] K.B. Snow, T.F. Thomas. Mass spectrum, ionization potential, and appearance potentials for fragment ions of sulfuric acid vapor. Int. J. Mass Spectrom. Ion Processes. 1990. Vol.96. No.1. P.49-68. https://doi.org/10.1016/0168-1176(90)80041-Z

[15] C. Lee, W. Yang, R.G. Parr. Development of the Colle-Salvetti correlation-energy formula into a functional of the electron density. Phys. Rev B. 1988. Vol.37. P.785-789. https://doi.org/10.1103/physrevb.37.785

[16] H. Dunning. Gaussian basis sets for use in correlated molecular calculations. I. The atoms boron through neon and hydrogen. J. Chem. Phys. 1989. Vol.90. P.1007-1023. https://doi.org/10.1063/1.456153

[17] D.E. Woon, and T.H. Dunning. Gaussian basis sets for use in correlated molecular calculations. III. The atoms aluminum through argon. Jr. J. Chem. Phys. 1993. Vol.98. P.1358-1371. https://doi.org/10.1063/1.464303.

[18] M. Head-Gordon, J.A. Pople, M.J. Frisch. MP2 energy evaluation by direct methods. Chemical Physics Letters. 1988. Vol.153. No.6. P.503-506. https://doi.org/10.1016/0009-2614(88)85250-3

[19] A.A. Granovsky. Firefly version 8, www http://classic.chem.msu.su/gran/firefly/index.html

[20] R.F.W. Bader. Atoms in Molecules, in Encyclopedia of Computational Chemistry. John Wiley and Sons, Chichester. 1998. P.64-86.

[21] T.A. Keith. AIMAll (Version 19.10.12), TK Gristmill Software [Electronic resource]: URL: aim.tkgristmill.com (access date: 02.08.2020).

[22] A.R. Allouche. Gabedit - A graphical user interface for computational chemistry softwares. Journal of Computational Chemistry. 2011. Vol.32. P.174-182. https://doi.org/10.1002/jcc.21600

[23] R.G. Parr, R.G. Pearson. Absolute hardness: companion parameter to absolute electronegativity. J. Am. Chem. Soc. 1983. Vol.105. No.26. P.7512-7516. https://doi.org/0.1021/ja00364a005

[24] R.G. Parr, R.A. Donnelly, M. Levy, W.E. Palke. Electronegativity: The density functional viewpoint. $J$ Chem Phys. 1978. Vol.68. P.3801-3807. https://doi.org/10.1063/1.436185

[25] P.K. Chattaraj, U. Sarkar, D.R. Roy. Electrophilicity Index. J. Chem. Rev. 2006. Vol.106. P.2065-2091. https://doi.org/10.1021/cr040109f 